\title{
Discípulo ou rival? A imagem de Simão Pedro no Quarto Evangelho a partir de Jo 21,1-14
}

\author{
Disciple or rival? \\ The image of Simon Peter in the Fourth Gospel \\ according to Jo $21,1-14$
}

Heitor Carlos Santos Utrini

\section{Resumo}

Depois de Jesus, a figura de Simão Pedro é a que mais se destaca nos evangelhos. Se existe um certo consenso entre os estudiosos em afirmar sua importância nos Sinóticos, o mesmo não se verifica acerca do Evangelho de João. São muitos os exegetas que julgam que a imagem de Simão Pedro no IV Evangelho é deliberadamente diminuída pelo evangelista, razão pela qual afirmam haver aí um conflito entre duas correntes na igreja primitiva representadas por Pedro e pelo discípulo amado. O presente artigo refletirá sobre a imagem que se depreende de Simão Pedro a partir de João. À luz de Jo 21,1-14 serão analisados os outros textos nos quais a figura de Pedro é mencionada a fim de se verificar se o que existe é uma disputa ou, ao contrário, se os personagens se complementam.

Palavras-chave: Pedro. Evangelho de João. Discípulo Amado. Cristianismo Primitivo. Discipulado.

\section{Abstract}

After Jesus, the figure of Simon Peter is the one that stands out on the Gospels. If there is a certain agreement among the scholars in stating his 
importance in the Synoptics, the same does not apply about the Gospel of John. Many are the exegetes that judge that the figure of Simon Peter on the Fourth Gospel is reduced deliberately by the evangelist, which is the reason why they claim there is a conflict between the two currents in the early church, represented by Peter and the beloved disciple. This article will reflect on the image that emerges from Simon Peter according to John. In the light of John 21,1-14, the other texts on which the figure of Peter is mentioned will be analyzed in order to verify if what exists is a conflict or, on the contrary, if the characters complement one another.

Keywords: Peter. Gospel of John. Beloved Disciple. Early Christianity. Discipleship.

\section{Introdução}

Depois do nome de Jesus, o personagem mais citado no Novo Testamento

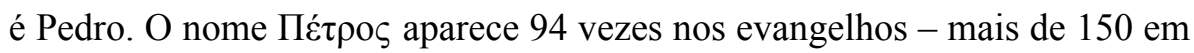

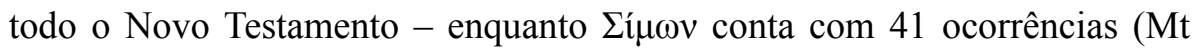

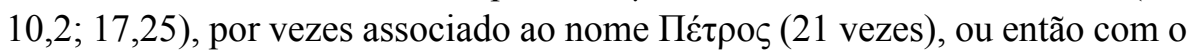

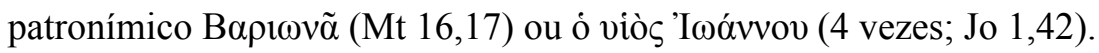

É inegável o lugar que é atribuído a Pedro pelos Evangelhos Sinóticos. Ele é o primeiro discípulo a ser chamado pelo Senhor (Mc 1,16-18 e par.) e o primeiro a ser mencionado nas listas dos Doze apóstolos (3,16-19 e par.). Coube a ele fazer a primeira profissão de fé em Jesus reconhecendo-o como Cristo (Mc 8,29 e par) e ele foi considerado a primeira testemunha da ressurreição (Lc 24,34; 1Cor 15,5). ${ }^{1}$ Mateus coloca nos lábios de Jesus um macarismo dirigido a Simão após sua profissão de fé (Mt 16,17) e a passagem de Marcos na qual Jesus censura Pedro chamando-o de $\Sigma \alpha \tau \alpha v \alpha \tilde{\varsigma}($ Mc 8,33) é simplesmente suprimida em Lucas (Lc 9,22-26). ${ }^{2}$

Pedro, juntamente com Tiago e João, é chamado de "coluna" da igreja pelo apóstolo Paulo (G1 2,9) e mesmo na comunidade de Corinto, uma igreja

\footnotetext{
${ }^{1}$ Embora seja considerado a primeira testemunha da ressurreição, na verdade, todos os evangelhos falam que as mulheres foram aquelas que pela primeira vez tiveram contato com o evento da ressurreição (Mc 16,1-8; Mt 28,9-10; Lc 24,1-7) e, no caso de Maria Madalena, com o próprio Ressuscitado (Jo 20,1-18). Entretanto, como o testemunho das mulheres não tinha nenhum valor jurídico, a Igreja apoiou a afirmação da boa-nova da ressurreição na autoridade de Pedro.

${ }^{2}$ A respeito desse tema, consultar VAN CANGH, J.-M., Le rôle de Pierre dans le Nouveau Testament, p. 41-62.
} 
fundada por Paulo, havia pessoas que se diziam pertencentes ao partido de Cefas (1Cor 1,12). É ele o personagem principal da primeira parte dos Atos dos Apóstolos (At 1,15-26; 2,14-36; 3,1-26; 4,1-5,33; 9,32-11,18) e tal era a importância de Pedro no final do primeiro século e início do segundo que duas cartas foram a ele atribuídas.

Apesar do lugar de destaque concedido ao apóstolo Pedro no Novo Testamento, aparentemente o Quarto Evangelho é um ponto fora da curva. Não poucos autores sustentam que a visão acerca de Simão Pedro no evangelho de João não é positiva. Afirmam que a intenção do quarto evangelista seria submeter Pedro à figura do Discípulo Amado, suprimindo daquele sua primazia sobre os outros discípulos. ${ }^{3}$ Segundo eles, paira sobre Pedro, em todo evangelho de João, a sombra da incredulidade e da incompreensão do Mestre, ao passo que o Discípulo Amado - o discípulo por excelência - refletiria o ideal a ser buscado.

O presente artigo tem por escopo refletir sobre a imagem do personagem Simão Pedro no Quarto Evangelho. O ponto de partida será o texto da pesca milagrosa por ocasião da terceira aparição do Ressuscitado no lago de Tiberíades (Jo 21,1-14). A partir das indicações da perícope, os outros textos joaninos nos quais a figura de Pedro aparece serão brevemente tratados para se apreender a imagem de Simão que emerge dessas páginas.

\section{O texto de Jo 21,1-14}

\begin{tabular}{|c|c|c|c|}
\hline $1 \mathrm{a}$ & $\begin{array}{l}\text { Depois disso, Jesus se manifestou } \\
\text { de novo aos discípulos junto ao }{ }^{4} \\
\text { mar de Tiberíades. } \\
\text { Manifestou-se assim: }\end{array}$ & 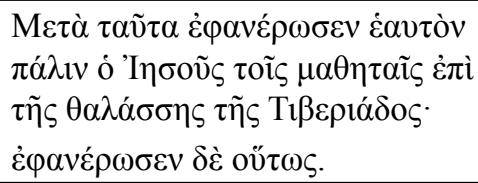 & $\begin{array}{l}1 \mathrm{a} \\
1 \mathrm{~b}\end{array}$ \\
\hline 2 & $\begin{array}{l}\text { Estavam juntos Simão Pedro e } \\
\text { Tomé, chamado Dídimo, Natanael } \\
\text { de Caná da Galileia e os [filhos] } \\
\text { de Zebedeu e outros dois de seus } \\
\text { discípulos. }\end{array}$ & 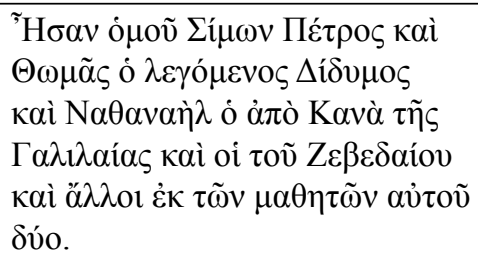 & 2 \\
\hline
\end{tabular}

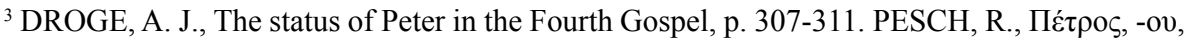
col. 923 .

${ }^{4}$ Sobre o sentido de غ̇ंí seguido de genitivo, vide BLASS, F.; DEBRUNNER, A., Grammatica del Greco del Nuovo Testamento, § 234,2 (doravante BD). 


\begin{tabular}{|c|c|c|c|}
\hline $3 a$ & Disse-lhes ${ }^{5}$ Simão Pedro: & 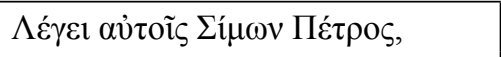 & $3 a$ \\
\hline $3 b$ & "Vou pescar". & 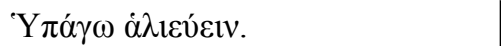 & $3 b$ \\
\hline $3 c$ & Disseram-lhe: & 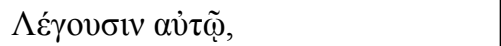 & $3 \mathrm{c}$ \\
\hline $3 \mathrm{c}$ & "Vamos também nós contigo". & 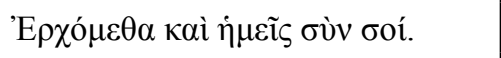 & $3 d$ \\
\hline $3 e$ & $\begin{array}{l}\text { Saíram e subiram na barca } \\
\text { imediatamente }\end{array}$ & 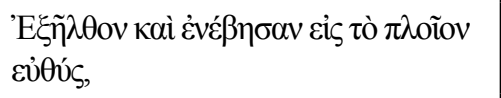 & $3 e$ \\
\hline $3 f$ & $\begin{array}{l}\text { e naquela noite não apanharam } \\
\text { nada. }\end{array}$ & 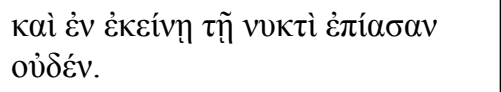 & $3 f$ \\
\hline $4 a$ & Mas quando a manhã já surgia, & 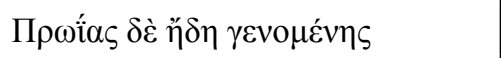 & $4 a$ \\
\hline $4 b$ & Jesus estava de pé na margem. & 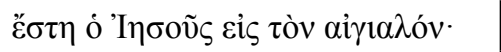 & $4 \mathrm{~b}$ \\
\hline $4 \mathrm{c}$ & $\begin{array}{l}\text { Entretanto, os discípulos não } \\
\text { sabiam que era Jesus. }\end{array}$ & 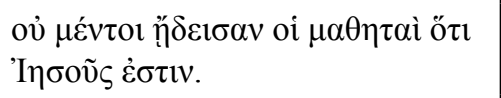 & $4 \mathrm{c}$ \\
\hline $5 a$ & Então Jesus lhes disse: & 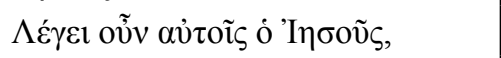 & $5 a$ \\
\hline $5 b$ & $\begin{array}{l}\text { "Moços, não }{ }^{6} \text { tendes alguma coisa } \\
\text { para comer" } 7\end{array}$ & 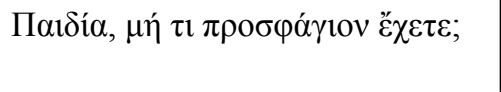 & $5 b$ \\
\hline $5 \mathrm{c}$ & Responderam-lhe: “Não!” & 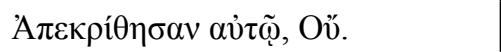 & $5 \mathrm{c}$ \\
\hline $6 a$ & Mas ele lhes disse: & O $\delta \varepsilon \dot{\varepsilon} \varepsilon \tilde{i} \pi \varepsilon v \alpha u ̉ \tau o \tilde{\iota} \zeta$ & $6 a$ \\
\hline $6 b$ & $\begin{array}{l}\text { "Lançai para o lado direito do } \\
\text { barco a rede e achareis". }\end{array}$ & 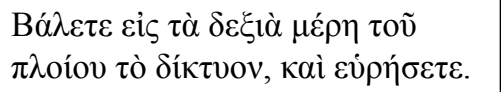 & $6 b$ \\
\hline $6 c$ & Então lançaram & "E $\beta \alpha \lambda$ ov oũv, & $6 c$ \\
\hline $6 \mathrm{~d}$ & $\begin{array}{l}\text { e não mais tinham forças para } \\
\text { puxá-la por causa da multidão dos } \\
\text { peixes. }\end{array}$ & 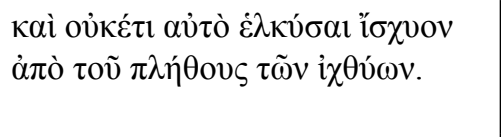 & $6 \mathrm{~d}$ \\
\hline $7 \mathrm{a}$ & $\begin{array}{l}\text { Disse então a Pedro aquele } \\
\text { discípulo a quem Jesus amava: }\end{array}$ & 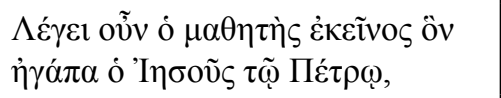 & $7 \mathrm{a}$ \\
\hline $7 b$ & "É o Senhor!" & O кúpıó & $7 b$ \\
\hline $7 \mathrm{c}$ & $\begin{array}{l}\text { Então Simão Pedro, tendo ouvido } \\
\text { que é o Senhor, }\end{array}$ & 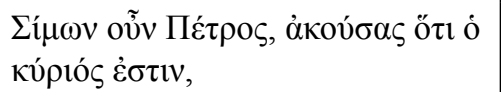 & $7 \mathrm{c}$ \\
\hline $7 d$ & $\begin{array}{l}\text { cingiu a veste - com efeito, } \\
\text { estava nu }\end{array}$ & 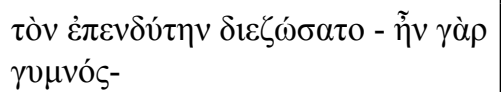 & $7 d$ \\
\hline
\end{tabular}

\footnotetext{
${ }^{5}$ Verbo no presente histórico. O mesmo acontece em 5a.4c.7a.9b.12a.12d.13a.13b.13c.

${ }^{6} \mathrm{~A}$ pergunta introduzida pela partícula $\mu$ 门́ supõe uma resposta negativa (BD §440).

${ }^{7}$ A palavra $\pi \rho 0 \sigma \varphi \alpha ́ \gamma \gamma$ iov originalmente designava qualquer alimento que era comido com o pão. Uma vez que era muito comum o acompanhamento de peixe, então a palavra passou a ser um sinônimo para pescado. Esse é um dos termos utilizados pelo autor para se referir ao peixe nesse

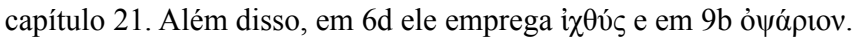




\begin{tabular}{|c|c|c|c|}
\hline $7 e$ & - e lançou-se no mar. & 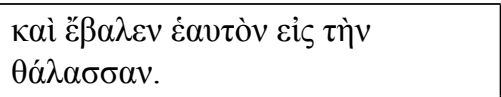 & $7 \mathrm{e}$ \\
\hline $8 \mathrm{a}$ & $\begin{array}{l}\text { Então os outros discípulos foram } \\
\text { com a barca }\end{array}$ & 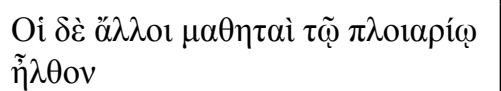 & $8 \mathrm{a}$ \\
\hline $8 b$ & $\begin{array}{l}\text { - de fato, não estavam longe } \\
\text { da terra, mas cerca de duzentos } \\
\text { côvados - }\end{array}$ & 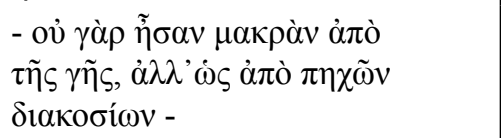 & $8 \mathrm{~b}$ \\
\hline $8 \mathrm{c}$ & levando a rede dos peixes. & 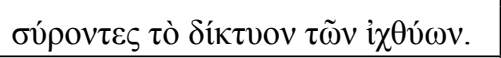 & $8 \mathrm{c}$ \\
\hline $9 \mathrm{a}$ & $\begin{array}{l}\text { E logo que desembarcaram para } \\
\text { a terra, }\end{array}$ & 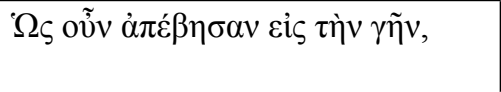 & $9 \mathrm{a}$ \\
\hline $9 b$ & $\begin{array}{l}\text { viram ali brasas, tendo em cima } \\
\text { peixe e pão. }\end{array}$ & 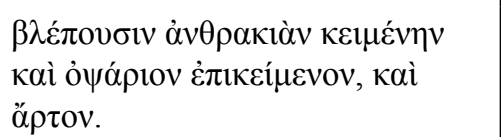 & $9 b$ \\
\hline $10 \mathrm{a}$ & Disse-lhes Jesus: & 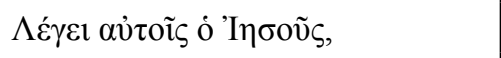 & $10 \mathrm{a}$ \\
\hline $10 \mathrm{~b}$ & $\begin{array}{l}\text { "Trazei agora [alguns] dos peixes } \\
\text { que apanhastes". }\end{array}$ & 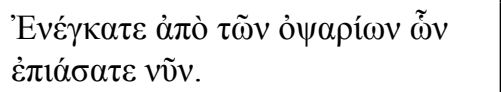 & $10 \mathrm{~b}$ \\
\hline $11 \mathrm{a}$ & Simão Pedro subiu & 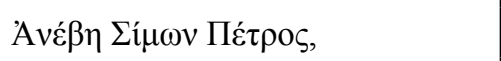 & $11 \mathrm{a}$ \\
\hline $11 b$ & $\begin{array}{l}\text { e puxou a rede para a terra } \\
\text { cheia de cento e cinquenta e três } \\
\text { grandes peixes; }\end{array}$ & 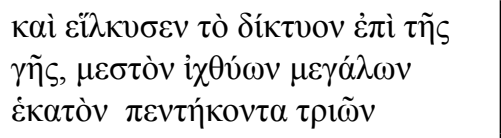 & $11 b$ \\
\hline $11 \mathrm{c}$ & $\begin{array}{l}\text { mesmo sendo tantos, a rede não } \\
\text { se rompeu. }\end{array}$ & 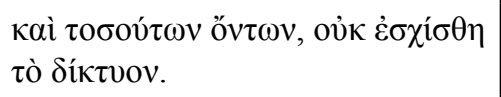 & $11 \mathrm{c}$ \\
\hline $12 \mathrm{a}$ & Disse-lhes Jesus: & 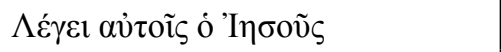 & $12 \mathrm{a}$ \\
\hline $12 b$ & "Vinde, comei!" & $\delta \varepsilon v \tilde{\varepsilon} \dot{\alpha} \rho t \sigma \tau \eta \dot{\sigma \alpha \tau \varepsilon . ~}$ & $12 b$ \\
\hline $12 \mathrm{c}$ & $\begin{array}{l}\text { Mas nenhum dos discípulos } \\
\text { ousava }^{8} \text { perguntar-lhe: }\end{array}$ & 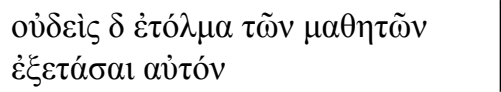 & $12 \mathrm{c}$ \\
\hline $12 d$ & $\begin{array}{l}\text { "Quem és tu?" tendo sabido que } \\
\text { era o Senhor. }\end{array}$ & 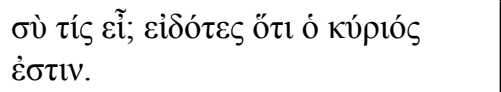 & $12 d$ \\
\hline $13 \mathrm{a}$ & Então, Jesus veio & 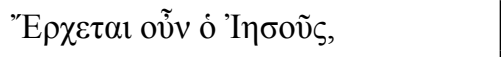 & $13 \mathrm{a}$ \\
\hline $13 b$ & e tomou o pão & 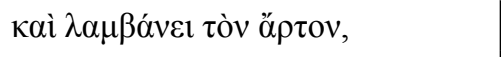 & $13 b$ \\
\hline $13 \mathrm{c}$ & $\begin{array}{l}\text { deu a eles e da mesma forma o } \\
\text { peixe. }\end{array}$ & 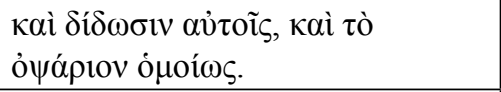 & $13 \mathrm{c}$ \\
\hline $14 \mathrm{a}$ & Esta já era a terceira vez & 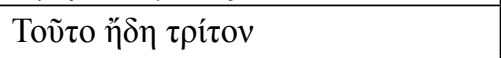 & $14 \mathrm{a}$ \\
\hline $14 b$ & $\begin{array}{l}\text { que Jesus se manifestou aos seus } \\
\text { discípulos }\end{array}$ & 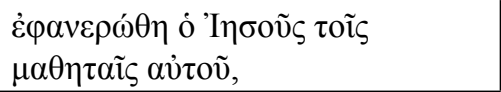 & $14 \mathrm{~b}$ \\
\hline
\end{tabular}

${ }^{8}$ O verbo aqui não tem o sentido de "atrever-se". A evidência da identidade de Jesus era tão nítida para os discípulos, que qualquer pergunta acerca de sua identidade seria desnecessária (MATEOS, J.; BARRETO, J., El Evangelio de Juan, p. 891). 


\begin{tabular}{|c|c|c|c|}
\hline $14 \mathrm{c}$ & $\begin{array}{l}\text { tendo sido ressuscitado dos } \\
\text { mortos. }\end{array}$ & 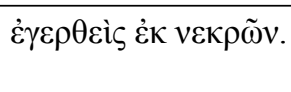 & $14 \mathrm{c}$ \\
\hline
\end{tabular}

\section{2. $O$ cap. 21 no contexto do IV Evangelho}

O modo como os estudiosos classificam o cap. 21 no contexto do inteiro Evangelho de João é bastante diversificado. Alguns imaginam que ele seria um acréscimo posterior que teria como objetivo corrigir algumas distorções, a saber, a imagem de Simão Pedro que deveria ser reabilitada com a narrativa da pesca e do diálogo sobre o pastoreio do rebanho de Jesus. ${ }^{9}$ Ver tal capítulo como uma adição equivale a afirmar que ele não afeta a leitura do evangelho. Outros autores preferem considerá-lo um epílogo que, retomando algumas ideias precedentes, completam alguns temas que ficaram em aberto. ${ }^{10} \mathrm{E}$, por fim, há ainda aqueles que o consideram uma obra do evangelista e a perfeita conclusão da narrativa evangélica. ${ }^{11}$

Com efeito, para a maior parte dos estudiosos, os argumentos a favor de uma autoria joanina parecem não ser tão determinantes quanto aqueles que apelam para a existência de um redator final. Apesar de haver alguns pontos de contato entre o cap. 21 e o restante do Evangelho, seja quanto aos temas, seja quanto ao vocabulário, não há como negar certas incongruências.

a) Antes de tudo, em 20,30-31 há uma conclusão teológica ao evangelho; ${ }^{12}$

b) $\mathrm{O}$ aparecimento de certos elementos que estão em desacordo com o resto do evangelho, tais como: a única menção aos filhos de Zebedeu (v. 2); a informação sobre a proveniência de Natanael (v. 2); até agora não se tinha falado que os discípulos eram pescadores; o uso

\footnotetext{
${ }^{9}$ AGOURIDES, S., The purpose of John 21, p. 127-132. DROGE, A. J., The status of Peter in the Fourth Gospel, p. 307-311.

${ }^{10}$ BROWN, R., El Evangelio según Juan, p. 1527-1529, v.2. ZUMSTEIN, J., El Evangelio según Juan, p. 382-384, v.2. MOLONEY, F. J., El Evangelio de Juan, p. 567-569. LÉONDUFOUR, X., Lectura del Evangelio de Juan, p. 219-222, v.4.

${ }^{11}$ SCHNEIDERS, S. M., John 21:1-14, p. 70-75. MATEOS, J.; BARRETO, J., El Evangelio de Juan, p. 887-888. BRODIE, T. L., The Gospel according to John, p. 574-576. MINEAR, P. S., The original functions of John 21, p. 85-98. SCHNEIDERS, S. M., John 21:1-14, p. 71. KEENER, K. S., The Gospel of John, p. 1219-1222.

${ }^{12}$ Os defensores da autoria joanina do cap. 21 sustentam que a conclusão de 20,30-31 é a conclusão da história daquilo que Jesus fez na presença de seus discípulos durante sua vida e mesmo do mistério pascal. Já a conclusão de 21,24-25 se referiria a todas as muitas coisas que ele ainda continua a fazer e que não poderiam ser escritas, pois não caberiam nos livros. Assim, o cap. 21 diria respeito ao que ainda está a acontecer (SCHNEIDERS, S. M., John 21:1-14, p. 75).
} 
da preposição ảสó com sentido partitivo (v. 10b); a mudança de foco teológico que ao longo do evangelho fora cristológica para uma eclesiológica no cap. $21 ;^{13}$

c) A própria atitude dos discípulos parece não ser muito coerente no cap. 21, pois se em 20,21-23 os discípulos tinham sido enviados na força do Espírito para comunicarem o perdão dos pecados, não se compreende porque tenham decidido voltar para a Galileia assumindo a função de pescadores; $;^{14}$

d) Além disso, como os discípulos podem não reconhecer o Senhor Ressuscitado se no cap. 20 os mesmos discípulos recebem uma aparição?

e) Por fim, o Jo 20,29 contém um macarismo sobre os que creem sem terem visto Jesus. Aparentemente o cap. 21 deixa a bem-aventurança esvaziada de seu peso por acrescentar uma nova aparição aos discípulos.

Apesar de o escopo do presente artigo não ser o de oferecer uma solução para a questão da autenticidade de Jo 21, esse é um problema que não poderia deixar de ser afrontado. Como se percebe, alguns dos argumentos acima enumerados são contestados pelos especialistas que defendem a autoria joanina, a ponto de tal autoria ser vista como plausível para muitos pesquisadores atuais. Ademais, na tradição manuscrita não sobreviveu uma cópia sequer do Quarto Evangelho que não contivesse o cap. 21.

Contudo, considerando os argumentos que evidenciam uma certa descontinuidade entre os cap. 20 e 21, seria mais prudente admitir que o cap. 21 seja um epílogo ao evangelho. No entanto, deve-se afirmar que toda a narrativa possui um colorido joanino e é provável que esse redator final tenha querido preservar esse material que ficou de fora na composição do evangelho. Ao incluí-lo aqui, o redator não se mantém distante do restante do evangelho, mas o vincula com respeito e cumplicidade. ${ }^{15}$

\footnotetext{
${ }^{13}$ ZUMSTEIN, J., El Evangelio según Juan, p. 383, v.2. BROWN, R., El Evangelio según Juan, p. 1530, v.2.

${ }^{14}$ Brodie, que defende a autoria joanina do cap. 21, não vê nisso um retrocesso, justamente porque o evangelho anteriormente não tinha mencionado que eles eram pescadores (BRODIE, T. L., The Gospel according to John, p. 575).

${ }^{15}$ Zumstein sustenta que a "escola joanina" é a responsável pela composição desse capítulo final. Tal escola, de tal maneira respeitava o evangelho, que em vez de tentar costurar esse capítulo de alguma outra forma, preferiu respeitar a conclusão do cap. 20, e acrescentou essa última aparição à modo de epílogo (ZUMSTEIN, J., El Evangelio según Juan, p. 384, v.2). Brown supõe que esse redator final seria um discípulo do evangelista que, mais do que alterar o impacto do evangelho, tencionava completá-lo (BROWN, R., El Evangelio según Juan, p.
} 


\section{Comentário ao texto}

Como ficou evidenciado na tradução, o texto se divide em 4 momentos: ambientação (v. 1), pesca e aparição do Ressuscitado (vv. 2-8), refeição com o Ressuscitado (vv. 9-13), observação do editor (v. 14). O comentário ao texto obedecerá o mesmo esquema.

\subsection{Ambientação}

Diferentemente das aparições anteriores, a descrição dessa manifestação do Ressuscitado é introduzida por uma vaga expressão temporal ( $\mu \varepsilon \tau \grave{\alpha} \tau \alpha \tilde{v} \tau \alpha$, v. 1). Contudo, se o autor não oferece um dado cronológico preciso, o mesmo não se pode dizer sobre o lugar. A aparição ocorre junto ao Mar de Tiberíades

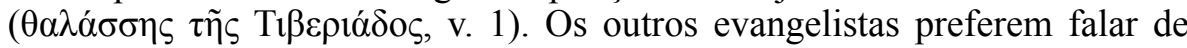

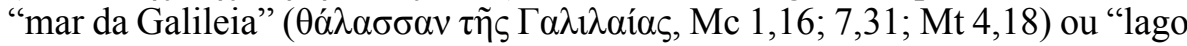

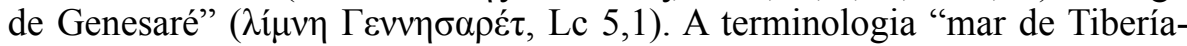
des" poderia ser mais compreensível para os seus leitores.

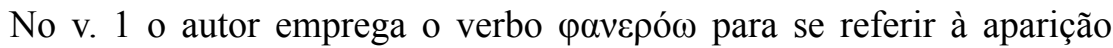
do Ressuscitado. Tal terminologia não fora empregada no cap. 20. Ali o evangelista se contentava em dizer que Jesus "veio" ( $\tilde{\eta} \lambda \theta \varepsilon v, 20,19.26)$, tendo

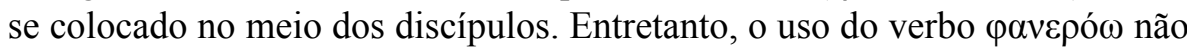
é estranho ao evangelista, ${ }^{16}$ significando aqui o "concreto fazer-se visível, o ato óptico-gnoseológico, para sublinhar a atividade salvífica de Deus operante nos sinais e nas palavras do Jesus terreno e ressuscitado". ${ }^{17}$

\subsection{Pesca e aparição do Ressuscitado}

Os personagens são apresentados no v. 2. Alguns desses nomes receberam bastante destaque ao longo do evangelho, como Simão Pedro e Tomé, este último mencionado cinco vezes ao longo do evangelho $(11,16 ; 14,5$; 20,24.26.28). Outros nomes são surpreendentes, como é o caso dos filhos de Zebedeu, cujos nomes só sabemos por causa dos evangelhos sinóticos (Mc 1,19 e par.). Assim como na cena inicial do chamado dos primeiros discípulos na qual nem todos os nomes são revelados, mas o evangelista mantém alguns sob o anonimato, aqui também há dois incógnitos. Mais adiante o redator dará

1530-1531, v.2).

${ }^{16}$ Além das três ocorrências no cap. 21 (vv. 1 [2x] e 14), temos mais seis ao longo do evangelho $(1,31 ; 2,11 ; 3,21 ; 7,4 ; 9,3 ; 17,6)$.

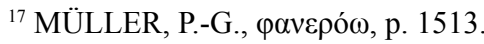


a informação de que um desses discípulos se trata daquele que Jesus amava (v. 7a). De qualquer forma, apesar de não serem doze os discípulos - número que configura o grupo apostólico - o número sete também dá a ideia de algo completo, perfeito, inteiro. Dessa forma, toda a comunidade está aqui representada. ${ }^{18}$

Essa é a primeira vez que a atividade pesqueira é associada à figura dos discípulos. Seja como for, Simão Pedro toma a iniciativa e é seguido pelos outros discípulos. ${ }^{19}$ Entretanto, todo esse trabalho que se desenrolou durante a noite deu em nada. ${ }^{20}$ Aqui é provável que o simbolismo joanino entre luztrevas desempenhe um papel importante. O trabalho infrutífero é aquele que acontece sem Jesus (Jo 15,5b). ${ }^{21}$

A chegada da luz do dia coincide com o aparecimento de Jesus nas margens do mar de Tiberíades (v. 4ab. Vide Jo 8,12; 9,5). O redator registra a total incapacidade de todos os discípulos reconhecerem de quem se tratava (v. 4c). O diálogo entre Jesus e seus discípulos começa com um vocativo inusitado para o evangelho: $\pi \alpha 1 \delta i ́ \alpha$ (v. 5b). No contexto do discurso de despedida da

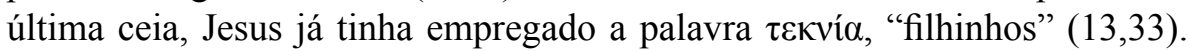
Mas ali tal apelativo com essa intensa carga emocional se justificava. Aqui, no entanto, traduzir $\pi \alpha \iota \delta i ́ \alpha$ por "filhinhos", embora tenha o suporte da tradição joanina que apoia o significado ( 1 Jo 2,$18 ; 3,7$ ), parece não ser a tradução mais feliz. Afinal, como um estranho poderia se dirigir com tamanha intimidade ao grupo sem que a sua identidade fosse imediatamente descoberta? ${ }^{22}$

\footnotetext{
${ }^{18}$ MATEOS, J.; BARRETO, J., El Evangelio de Juan, p. 892.

${ }^{19}$ Um texto corrompido do apócrifo intitulado Evangelho de Pedro, escrito por volta de 130-150, traz a mesma notícia. Com efeito, ali se lê: "Era o último dia dos ázimos e muita gente saía da cidade para voltar para suas casas, tendo terminado a solenidade. Nós, os doze apóstolos do Senhor, chorávamos e nos entristecíamos. Então cada um, aflito pelo que tinha acontecido, voltou à sua casa. Simão Pedro, com André, meu irmão, tomamos nossas redes, e fomos até o mar. Conosco estava Levi, o filho de Alfeu, que o Senhor..." (tradução nossa). Aqui o texto termina, mas pode-se perceber alguns pontos de contato com o IV Evangelho. Para uma visão integral do texto apócrifo, vide ERBETTA, M., Gli Apocrifi del Nuovo Testamento, p. 137-145, v.I/1.

${ }^{20}$ Aqui o redator usa um verbo pouco comum para designar a pesca. Ele emprega o verbo $\pi \mathrm{a} \alpha \zeta \zeta$, cujo significado elementar é o de "pressionar", "apertar", “comprimir”, “oprimir”, "prevalecer" (LIDDELL, H. G.; SCOTT, R., Greek-English Lexicon, p. 1402). Zorell destaca os sentidos de "premo", "manu compressa teneo", "manu prehendo", "capio, corripio", este último referido ao presente texto (ZORELL, F., Lexicon Graecum Novi Testamenti, col. 1052).

${ }^{21}$ A pesca sem Jesus é o retrato de uma atitude, mais do que a mera descrição de um fato (MATEOS, J.; BARRETO, J., El Evangelio de Juan, p. 895).

${ }^{22}$ BROWN, R., El Evangelio según Juan, p. 1517, v.2. Zumstein percebe no apelativo um forte tom eclesiológico. Segundo ele, trata-se da relação entre o Ressuscitado com sua comunidade (ZUMSTEIN, J., El Evangelio según Juan, p. 390, v.2). No entanto, segundo Moloney, o apela-
} 
Depois da resposta negativa por parte dos discípulos (5c), Jesus ordena que lancem a rede à direita da barca (6b). Ao obedecerem à ordem do Senhor (6c), o resultado da pesca foi tão abundante a ponto de os discípulos não terem forças para puxar a rede para dentro da embarcação (v. 6d). $\mathrm{O}$ texto fala da

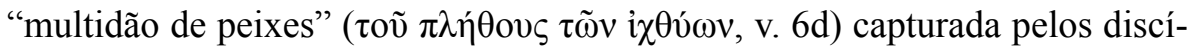
pulos. O termo $\pi \lambda \eta \dot{\theta} \theta$ o tinha aparecido apenas uma outra vez em Jo 5,3 quando descreve uma "multidão de enfermos" ( $\pi \lambda \tilde{\eta} \theta 0 \varsigma \tau \tilde{\omega} v \dot{\alpha} \sigma \theta \varepsilon v o v ́ v \tau \omega v)$ junto da piscina de Betesda, por ocasião da cura do paralítico. ${ }^{23}$

Diante do resultado da pesca, o "discípulo que Jesus amava" reconhece o Ressuscitado e diz a Simão Pedro: "É o Senhor!" (v. 7ab). Diante de tal profissão de fé, Simão Pedro cingiu o manto e pulou na água (v. 7de). Antes de tudo é necessário recordar que o $\mathrm{v} .7 \mathrm{~d}$ faz referência à nudez do discípulo

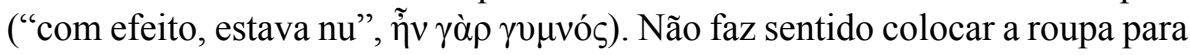
depois pular na água e nadar até Jesus.

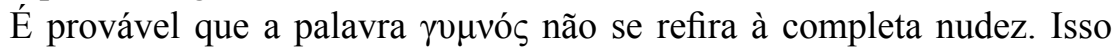
porque tal estado contraria as normas de pudor dos judeus e, sobretudo, porque o trabalho aconteceu durante o frio da noite. Acerca da roupa usada por Simão Pedro, o redator fala que se tratava de $\dot{\epsilon} \pi \varepsilon v \delta v ́ \tau \eta \zeta$, que literalmente é uma "roupa de cima". Os autores creem que se tratava de uma espécie de blusão largo, próprio para a faina. Simão Pedro se cinge para poder nadar com mais liberdade, sem ser incomodado pela roupa. Logo depois o autor informa que os demais discípulos também vieram arrastando a rede com os peixes. ${ }^{24}$

Acerca do verbo $\delta 1 \alpha \zeta \omega ́ v v v \mu$, aqui traduzido por "cingir-se" (v. 7d), ele aparece apenas mais duas outras vezes no evangelho, ambas no mesmo contexto. Essa é a palavra empregada pelo evangelista para descrever o gesto de Jesus na última ceia. Diz o evangelista que ele se levantou, depôs o manto,

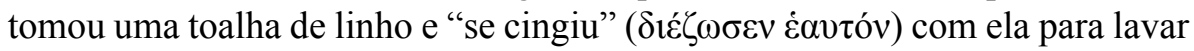
os pés aos discípulos (Jo 13,4.5). Alguns autores veem aqui uma intenção simbólica por detrás da escolha dessa palavra. Assim como o gesto do lava-pés era o sinal do serviço de Jesus disposto a dar sua própria vida pelos homens, da mesma forma Pedro poderia ter finalmente entendido o que significa ser discípulo por meio da imitação da atitude do Mestre. ${ }^{25}$

tivo "moços" não faria justiça à relação de autoridade entre Jesus e os discípulos e mesmo ao modo como o autor da 1 Jo se dirige aos seus destinatários (MOLONEY, F. J., El Evangelio de Juan, p. 558).

${ }^{23} \mathrm{O}$ termo é tipicamente lucano. Para maiores informações, consultar ZMIJEWSKI, J., $\pi \lambda \tilde{\eta} \theta 0 \varsigma$, col. 972-977.

${ }^{24}$ BROWN, R., El Evangelio según Juan, p. 1519-1520, v.2.

${ }^{25}$ MATEOS, J.; BARRETO, J., El Evangelio de Juan, p. 898. 


\subsection{Refeição com o Ressuscitado (vv. 9-13)}

Ao desembarcarem, os discípulos são recebidos com uma refeição. Eles veem brasas acesas, sobre as quais havia pão e peixe (v. 9b). Os leitores do evangelho automaticamente se recordam do episódio narrado no cap. 6 , também esse às margens do mar de Tiberíades, no qual Jesus mata a fome de uma multidão com cinco pães e dois peixes (Jo 6,1-15). As implicações eucarísticas são evidentes nos dois casos, pois os discípulos se encontram com o Ressuscitado durante a refeição que ele mesmo oferece.

No v. 10b Jesus ordena que os discípulos tragam alguns dos peixes que eles mesmos tinham apanhado, mas a ordem é executada apenas por Simão Pedro (v. 11ab). É surpreendente que Pedro tenha conseguido arrastar sozinho para a terra uma rede repleta de peixes sobre a qual pouco antes se dizia que todos os discípulos não conseguiam puxá-la (v. 6d). A respeito desse versículo, duas observações podem ser feitas. Primeiramente, muito se escreveu sobre o número de peixes ("cento e cinquenta e três", 11b), mas até agora essa cifra permanece um mistério. ${ }^{26}$ Como todas as interpretações carregam grande grau de incerteza, melhor é simplesmente reconhecer que o significado numérico - se havia algum - se perdeu. Pode-se admitir, contudo, que o redator queira com ele indicar a superabundância e a universalidade da igreja cristã. ${ }^{27}$

Ignorar o sentido no número não altera a compreensão da perícope, pois o que realmente importa é dito no v. 11c: "mesmo sendo tantos, a rede não se rompeu". Esta é a segunda vez que, no texto, o redator faz alusão ao tema da unidade. A primeira fora no v. 2 ao dizer que os discípulos "estavam juntos" ( ensinamento (Jo 17,11.21). ${ }^{28}$ No presente versículo, a rede que não se rompe apesar da quantidade de peixes é o símbolo da comunidade cristã congregada pela atividade missionária dos discípulos que traz as pessoas até Jesus. Vê-se aqui insinuada a alusão à túnica inconsútil cuja integridade foi preservada pelos soldados no momento da crucifixão (Jo 19,23-24).

Os vv. 12 e 13 narram a refeição com o Ressuscitado e o reconhecimento do Senhor por parte dos discípulos. Salta aos olhos a nota que o redator acrescentou no v. 12cd: "Mas nenhum dos discípulos ousava perguntar-lhe: 'Quem

\footnotetext{
${ }^{26}$ Acerca dos principais significados atribuídos ao número 153, vide BROWN, R., El Evangelio según Juan, p. 1522-1524, v.2. Sobre o mesmo tema, OAKMAN, D., The political meaning of a cipher, p. 87-94.

${ }^{27}$ ZUMSTEIN, J., El Evangelio según Juan, p. 392, v.2.

${ }^{28}$ MATEOS, J.; BARRETO, J., El Evangelio de Juan, p. 893. TALBERT, C., Reading John, p. 269-270.
} 
és tu?' tendo sabido que era o Senhor". Essa reação tanto de surpresa quanto de estranhamento da parte dos discípulos diante do Ressuscitado é uma constante nos evangelhos canônicos. Mateus, por exemplo, por ocasião do envio missionário, acrescenta que os discípulos se encontraram com Jesus Ressuscitado na Galileia, no monte que lhes fora indicado. "Ao vê-lo, adoraram-no,

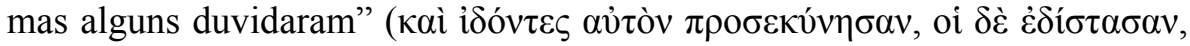
Mt 28,17). Da mesma forma, Lucas descreve que os discípulos que estavam a caminho de Emaús não reconheceram o Ressuscitado que caminhava com eles (Lc 24,15-16). Essa reação se explica pelo fato de o autor tentar traduzir com palavras uma experiência escatológica. Com efeito, é Jesus mesmo, mas não é o mesmo Jesus. O que o redator nos apresenta é a vida da comunidade que se encontra com o Ressuscitado na Eucaristia. ${ }^{29}$

Um último pormenor a ser mencionado é que os verbos do v. 13 estão no chamado "presente histórico" (num total de 151 ocorrências em Jo). Tal expediente além de deixar a narrativa mais vivaz, como se o acontecimento se desenrolasse nos dias do narrador, ${ }^{30}$ pode ter uma outra finalidade. As narrativas podem adquirir também uma intenção teológica distinta, a saber, a de apresentar a atualidade dos acontecimentos descritos no hoje da comunidade. ${ }^{31}$

Mas nem todos os autores veem nessa atitude de Simão Pedro um sinal de bom presságio. Para Gee, tanto o gesto de cingir-se, quanto o de pular na água, não têm um significado positivo na narrativa. O que teria movido Simão Pedro seriam o medo e a culpa. Tendo ouvido que era o Senhor, Pedro tentou fugir nadando para longe do Mestre, enquanto os discípulos foram até Jesus com a barca. Os discípulos se encontraram com o Senhor ao redor da fogueira e nesse ínterim Simão Pedro estaria escondido atrás da barca, ainda dentro da água. Por isso, ao ouvir a ordem de Jesus para que trouxessem alguns dos peixes, ele a executa por estar em posição mais propícia. ${ }^{32}$

\subsection{Observação do editor}

O v. 14 serve de elo entre essa aparição e as demais narradas no cap.

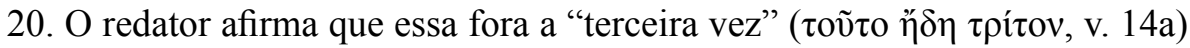
que Jesus se manifestou a seus discípulos após a ressurreição. Convém levar

\footnotetext{
${ }^{29}$ MOLONEY, F. J., El Evangelio de Juan, p. 556.

${ }^{30} \mathrm{BD} \S 321$.

${ }^{31}$ MOULTON, J. H.; TURNER, N., A Grammar of New Testament Greek, p. 20, v.4. Segundo Mateos e Barreto, o verbo "vir" no presente designa a chegada contínua de Jesus na comunidade, que se percebe na Eucaristia (MATEOS, J.; BARRETO, J., El Evangelio de Juan, p. 902).

${ }^{32}$ GEE, D. H., Why did Peter spring into the sea?, p.481-489.
} 
em conta o simbolismo do número três como símbolo da completude.$^{33}$ Esse comentário editorial serve para segmentar o cap. 21 em duas grandes partes. A primeira, como foi visto, é a pesca milagrosa e a refeição com o Ressuscitado (vv. 1-14), e a segunda é o diálogo entre Jesus e Simão Pedro no qual o Ressuscitado confia ao apóstolo os cuidados de seu rebanho (vv. 15-24).

\section{A imagem de Simão Pedro no IV Evangelho}

Antes de tratar da atuação de Simão Pedro no cap. 21, convém retornar à pergunta de base que motivou a presente pesquisa: seria de fato o cap. 21 uma espécie de reabilitação de Pedro? Ao longo do evangelho, a imagem que se depreende do apóstolo é negativa a ponto de necessitar ser corrigida? E mais: o evangelista, para ressaltar a importância do discípulo amado, precisava projetar uma sombra sobre Simão Pedro? Haveria então uma disputa entre eles ao longo do evangelho? São essas as questões que deverão ser afrontadas a partir de agora.

\subsection{Vocação dos primeiros discípulos (Jo 1,35-42)}

Marcos e Mateus apresentam o chamado de duas duplas de irmãos logo no início do ministério público de Jesus, durante uma pescaria (Mc 1,16-20; Mt 4,18-21). Em ambos os casos, os primeiros a serem mencionados são Simão e André. João, ao contrário, ambienta de maneira diversa o chamado dos discípulos: eles provêm do círculo do Batista (Jo 1,35-37). O primeiro

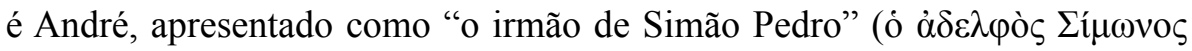

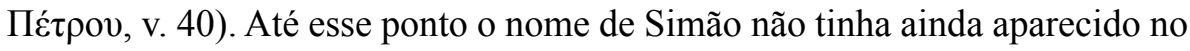
evangelho, o que leva a inferir que ele era alguém já conhecido pela comunidade. O segundo discípulo é anônimo e há quem suspeite que aqui já haja uma primeira referência ao discípulo amado, ${ }^{34}$ muito embora não seja possível uma total confirmação. ${ }^{35}$

$\mathrm{Na}$ continuação, o evangelista nota que André encontra "primeiro"

\footnotetext{
${ }^{33}$ São três os filhos de Noé (Gn 6,10), as bênçãos de Balaão a Israel (Nm 24,10), os amigos de Jó (Jó 2,11; 31,1), os amigos de Daniel (Dn 3,23-24), as tendas que Pedro quer construir no monte da transfiguração (Mc 9,5). Sobretudo, o número três se relaciona com o dia da ressurreição (Mc 8,31 e par.; 9,31 e par.; 10,34 e par.; Mt 12,40; Lc 24,7.21; Jo 2,19; 1Cor 15,4). Para maior aprofundamento sobre o tema, vide DELLING, G., $\tau \rho \varepsilon \tilde{\varsigma} \zeta, \kappa \tau \lambda$, p. 216-225.

${ }^{34}$ Essa é a opinião de BROWN, R., El Evangelio según Juan, p. 287, v.1.

${ }^{35}$ BLAINE JR., B. B., Peter in the Gospel of John, p. 31-32.
} 
( $\pi \rho \tilde{\omega} \tau o v)$ seu irmão Simão. O vocábulo pode ter o significado "primeiro no tempo", "em primeiro lugar", mas também de "primeiro em dignidade ou importância". ${ }^{36} \mathrm{O}$ fato de André ter sido apresentado como "irmão de Simão Pedro" e ter feito da evangelização de Pedro a sua prioridade, isso já mostra o lugar de Simão na narrativa. ${ }^{37}$ Está nos lábios de André a primeira identificação de Jesus como Messias $(1,41)$ no Evangelho. De qualquer forma, a concentração de títulos aplicados a Jesus no primeiro capítulo de João é algo a ser destacado. ${ }^{38}$

André conduziu seu irmão a Jesus que, fixando nele o olhar, impôs-lhe

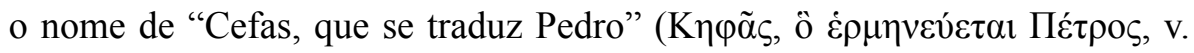
42). ${ }^{39}$ A mudança de nome nas histórias do AT marca um novo começo, uma nova relação com Deus e uma missão (Gn 17,5; 35,10). No presente caso, a mudança de nome está em função da cristologia: é o modo de João destacar a presciência de Jesus. O nome Cephas não parece descrever nenhum atributo de Pedro, uma vez que ainda não mostrou nenhum. ${ }^{40}$

É curioso que o autor não destaque nenhuma reação de Simão Pedro em seu primeiro encontro com Jesus. Os demais evangelistas falam de sua pronta resposta ao largar tudo para seguir o Senhor (Mc 1,18; Mt 4,20), ou de seu temor reverente depois da pesca milagrosa que o levou a dizer: "Afasta-te de mim, Senhor, porque sou um homem pecador" (Lc 5,8). Sequer há aqueles elementos comuns nos relatos de vocação, a saber, o convite de Jesus para o seguimento, o

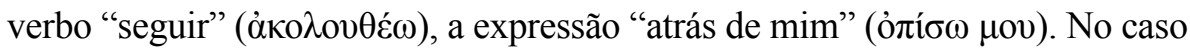
de Pedro, dada a sua importância, seu aprendizado para o discipulado durará todo o evangelho e apenas na última página, virá seu chamado $(21,19)$.

${ }^{36}$ LIDDELL, H. G.; SCOTT, R., Greek-English Lexicon, p. 1535. ZORELL, F., Lexicon Graecum, col. 1158-1161. Dessa forma lê BLAINE JR., B. B., Peter in the Gospel of John, p. 30. ${ }^{37}$ BLAINE JR., B. B., Peter in the Gospel of John, p. 35.

${ }^{38}$ Ele é chamado de Palavra $(1,1.14)$, Unigênito de Deus $(1,18)$, Cordeiro de Deus $(1,29.36)$, Filho de Deus (1,34.49), Rabi (1,38.49), Messias $(1,41)$, Aquele sobre o qual escreveu Moisés na Lei e nos Profetas $(1,45)$, Rei de Israel $(1,49)$, Filho do Homem $(1,51)$.

${ }^{39}$ Desde a Antiguidade, a identidade de Cefas, que foi repreendido por Paulo em Gl 2,11, foi questionada. Para se opor à primazia petrina, certos autores se apoiavam nessa passagem, o que levou Clemente de Alexandria em sua obra Hypotyposes a sustentar que se tratava de uma outra pessoa, a saber, um dos setenta discípulos de Jesus, homônimo de Pedro apóstolo (Apud EUSEBIO DE CESAREA, Historia Eclesiastica, I,12,2). Sobre o mesmo tema vide SCOTT, J. M., A question of identity, p. 1-20. LAKE, K., Simon, Cepas, Peter, p. 95-97. Acerca do nome Simão, vide FITZMYER, J. A., Essays on the Semitic Background of the New Testament, p. 105-112.

${ }^{40}$ BLAINE JR., B. B., Peter in the Gospel of John, p. 36-37. QUAST, K., Peter and the Beloved Disciple, p. 41. 
Segundo a cronologia do IV Evangelho, as primeiras palavras de Simão Pedro só serão ouvidas um ano mais tarde, por ocasião da segunda Páscoa. ${ }^{41}$ Após os episódios da multiplicação dos pães $(6,1-15)$ e da caminhada sobre as águas $(6,16-21)$, o evangelista registra um longo discurso pronunciado na sinagoga de Cafarnaum (6,22-59). Nesse sermão, Jesus se apresenta como o

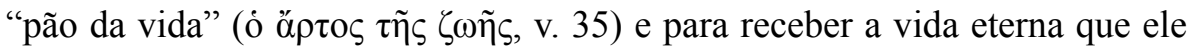
oferece, é necessário crer (v. 40). Em certo sentido, o termo "pão" se identifica com a mensagem trazida por Jesus, daí a necessidade da fé entendida como resposta do homem à proposta de Deus.

Entretanto, nos vv. 52-58 a temática caminha para outra direção. Jesus fala da necessidade de "comer a carne do Filho do Homem" e de "beber o seu sangue" (v. 53) como condição para se receber a vida eterna. Aqui, entretanto, o verbo "comer" não poderia ser entendido metaforicamente, no sentido de "aderir" ou “crer". O evangelista escolhe o verbo $\tau \rho \omega ́ \gamma \omega$ (v. 54.56.57) que significa "roer", "mordiscar", "mastigar". ${ }^{42}$ Aqui as palavras adquirem um colorido claramente eucarístico e apenas nesse sentido a dureza do termo pode ser desfeita.

A reação dos discípulos às palavras foi imediata: depois de murmurarem, muitos voltaram atrás e não mais andavam com ele (v. 66). Diante do escândalo e do abandono dos discípulos, Jesus pergunta se "os Doze" também não desejam ir embora (v. 67). Esse é o primeiro texto em todo evangelho que o termo oi $\delta \omega ́ \delta \varepsilon \kappa \alpha$ é utilizado. É nesse contexto de crise que surge a figura de Simão Pedro que fala em nome do grupo: "Senhor, a quem iremos? Tens palavras de vida eterna e nós cremos e sabemos que tu és o santo de Deus" (v. 68-69). ${ }^{43}$

Os demais evangelistas também colocam nos lábios de Pedro a sua profissão de fé após o episódio da multiplicação dos pães (Mc 8,29 e par.). No entanto, após tal profissão de fé, Marcos e Mateus relatam o desentendimento entre Pedro e Jesus depois do primeiro anúncio da paixão. Jesus repreende Pedro chamando-o de "Satanás" (Mc 8,33; Mt 16,23). Lucas simplesmente omite essa contenda em seu relato (Lc 9,21-27) e o mesmo faz João em seu

\footnotetext{
${ }^{41}$ A primeira Páscoa tinha sido mencionada em 2,13 e a segunda em 6,4.

${ }^{42}$ Segundo Zorell, "dentibus comminuo ac comedo fructus crudos vel edulia non cocta duriora", "comedo", "manduco" (ZORELL, F., Lexicon Graecum, col. 1340).

${ }^{43}$ Notar o uso da primeira pessoa plural em $\alpha \pi \varepsilon \lambda \varepsilon v \sigma o ́ \mu \varepsilon \theta \alpha, \pi \varepsilon \pi \imath \sigma \tau \varepsilon v ́ \kappa \alpha \mu \varepsilon v$ e $\varepsilon \gamma v \omega ́ \kappa \alpha \mu \varepsilon v$, bem como o pronome pessoal $\eta \mu \varepsilon i \tilde{s}$.
} 
texto. Aqui, ao contrário, existe um dos discípulos que é chamado de "diabo", mas não se trata de Simão, mas sim de Judas Iscariotes (vv. 70-71).

Segundo o esquema joanino, "discípulo" ( $\mu \alpha \theta \eta \tau \eta ́ \varsigma)$ de Jesus não é apenas um membro do grupo dos Doze. Aqui o conceito é mais amplo: José de Arimateia $(19,38)$, todo aquele que permanece na palavra de Jesus $(8,31)$ e aquele que ama seu irmão $(13,35)$, todos eles merecem o título de discípulo. A passagem ora analisada distingue "os Doze" (v. 67) e outros discípulos (v. 66). Muito embora os Doze não recebam o destaque que têm nos Sinóticos, seu papel ainda assim é importante. João os introduz na narrativa sem nenhuma apresentação prévia, pressupondo que o grupo já fosse conhecido por seus leitores.

Essa distinção é algo importante, porque alguns autores querem ver nessa passagem uma crítica do evangelista à profissão de fé de Pedro. Isso porque, segundo eles, o título "Santo de Deus" nos sinóticos é dado a Jesus apenas por endemoninhados (Mc 1,24; Lc 4,34). Dessa forma, Pedro seria porta-voz de uma cristologia equivocada - e por que não diabólica? - sustentada pelos Doze, pela Igreja Apostólica. ${ }^{44} \mathrm{Tal}$ argumento é desfeito ao se observar o uso da palavra ớ $\gamma$ ı̧ no IV Evangelho. Em 10,36 Jesus é apresentado como aquele a quem o Pai consagrou e enviou ao mundo. O verbo no aoristo ( $\eta_{\gamma} i^{\alpha} \alpha \varepsilon v$ ) pode indicar a encarnação do $\lambda$ ó $\gamma o \varsigma$. O próprio Jesus aplica a si esse verbo em

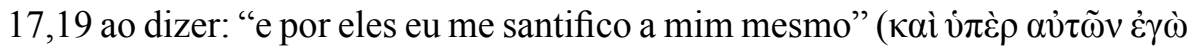

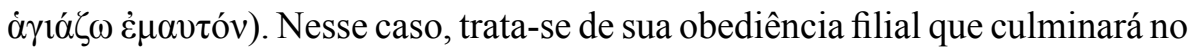
sacrifício da cruz. Em 17,17 Jesus pede que os discípulos sejam "santificados

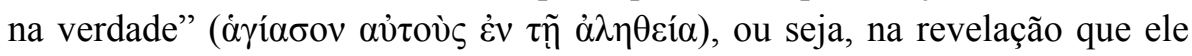
trouxe a respeito do Pai e em sua atitude filial. ${ }^{45}$

Não parece que o evangelista tenha querido indicar que os cristãos apostólicos sustentassem uma "cristologia baixa", diferentemente da comunidade joanina que admitia a preexistência de Jesus e sua origem do alto. ${ }^{46}$ Algumas coisas aqui devem ser observadas. Primeiramente, a pergunta que Jesus dirige aos Doze, não diz respeito à sua identidade. Diferentemente dos sinóticos que trazem: "E vós, quem dizeis que eu sou?" (Mc 8,29), aqui

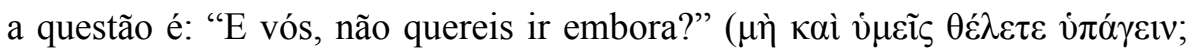
6,67). Portanto, o dilema de fundo não é sobre a identidade de Jesus, mas

\footnotetext{
${ }^{44}$ MAYNARD, A. H., The role of Peter in the Fourth Gospel, p. 534. SNYDER, G. F., John 13:16 and the Anti-Petrinism of the Johannine Tradition, p. 11.

${ }^{45}$ CABA, J., Cristo, pan de vida, p. 422-423.

${ }^{46}$ Isso é o que diz BROWN, R., A Comunidade do Discípulo Amado, p. 89.
} 
sobre a decisão dos discípulos. A presença do $\mu$ ń no início da frase já denota que ele esperava uma resposta negativa. ${ }^{47}$

Ademais, o título "santo de Deus" aplicado a Jesus parece perfeitamente cabível no contexto. Uma vez que o adjetivo "santo" denota a máxima intimidade com Deus, ele é assim chamado por ser o revelador por excelência do Pai, aquele que tem "palavras de vida eterna" (v. 68). Dessa forma, Pedro não é alguém que possua uma cristologia esquálida, mas responde à pergunta de forma clara. ${ }^{48}$ Diferentemente de Mt 16,13-20, após a profissão de fé não existe qualquer alusão a um "primado". De qualquer forma, ele se faz portavoz da lealdade do grupo dos discípulos.

\subsection{A última ceia $(13,1-38)$}

A figura de Simão Pedro se destaca em dois momentos na última ceia. Primeiramente, por ocasião da cena do lava-pés, quando chega a vez de Pedro, ele se opõe a Jesus afirmando: "Senhor, tu lavas os meus pés?" (v. 6). Aparentemente, o primeiro simbolismo apreendido pelos discípulos no gesto de Jesus foi o ensinamento acerca da humildade. ${ }^{49}$ Isso poderia ser entendido a partir do v. 14 quando Jesus afirma: "Então, se eu, o Senhor e Mestre, vos lavei os pés, também vós deveis lavar os pés uns dos outros". Visto de maneira simplória, o ato de Jesus subverteria a ordem segundo a qual o Mestre é quem deveria ser servido. ${ }^{50}$

No entanto, a lição que Jesus deseja transmitir não é apenas sobre a humildade. Diante da recusa de Pedro, ele mesmo afirma: "O que eu faço, tu

\footnotetext{
${ }^{47}$ Vide nota 6.

${ }^{48}$ BLAINE JR., B. B., Peter in the Gospel of John, p. 46-47.

${ }^{49} \mathrm{Na}$ história de José e Aseneth (séc. I a.C. - II d.C.), a filha do faraó recém-casada com José deseja lhe lavar os pés. Mas ele protesta, dizendo: "Deixa que uma das virgens venha e lave meus pés'. E Aseneth lhe disse: 'Não, meu senhor, porque tu és meu senhor de agora em diante e eu sou sua serva. Por que disseste que outra virgem lavaria teus pés? Teus pés são meus pés, tuas mãos são minhas mãos e tua alma minha alma, e outra mulher nunca tocará teus pés'. E ela insistiu com ele e lavou seus pés" (Joseh and Aseneth. In: CHARLESWORTH, J. J. (Ed.)., The Old Testament Pseudepifrapha, 20,2-4, v.2. [tradução nossa]). Tal gesto humilde parecia não ser adequado para uma esposa com relação ao marido. Sobre o simbolismo do gesto no judaísmo do séc. I e na literatura rabínica, vide MANNS, F., Exégèse rabbinique et exégèse johannique, p. 330-333.

${ }^{50}$ Como se vê, a reação de Simão Pedro é fruto de sua incompreensão do gesto de Jesus. Contudo, Maggi pensa de maneira diferente. Para ele, "o único discípulo que protesta é, na realidade, o único que compreendeu as consequências da ação do Senhor. Se Jesus, o Mestre, lava os pés dos discípulos, de agora em diante ninguém no grupo poderá considerar-se superior ao outro" (MAGGI, A., A Loucura de Deus, p. 131).
} 
agora não sabes, mas saberás depois disso" (v. 7). "Jesus realizou essa obra servil para anunciar simbolicamente a necessidade salvífica de sua morte, que daria aos homens a possibilidade de ter parte em sua herança e os limparia do pecado". ${ }^{51}$ Depois da "hora" de Jesus, Pedro entenderia sua atitude na ceia, que reflete sua disposição de se entregar pelos seus.

Quando o Senhor anuncia que se Simão Pedro não permitir ter os pés lavados não terá parte com ele, imediatamente ele se convence, pedindo que fossem lavados não apenas os pés, mas também as mãos e a cabeça (v. 9). Noutras palavras, Pedro pensava que para partilhar a herança de Jesus, quanto mais fosse lavado, mais parte teria com ele. ${ }^{52}$ É claro que a questão não era a quantidade de água, mas aceitar o amor gratuito de Jesus simbolizado no gesto. Pedro está de fato confuso por se concentrar exclusivamente na água e não na ação profética que ela representa. ${ }^{53}$

Os pontos de contato com o texto de 21,1-14 são inúmeros. Primeiramente, o verbo "cingir-se" em 13,4, no qual Jesus se cingiu com uma toalha, só aparecerá em 21,7. Dessa forma, Pedro assume a mesma atitude do Mestre no final do evangelho. Além disso, a expressão $\mu \varepsilon \tau \alpha \grave{~} \tau \alpha \tilde{\tau} \tau \alpha$ que apareceu em 13,7, ocorrerá novamente em 21,1, que é a única cena na qual Simão Pedro aparece e cuja fórmula ocorre. Sendo assim, o "depois disso" anunciado na última ceia chega a seu termo no cap. 21.

A cena do lava-pés é particularmente importante porque essa é a primeira vez que aparecem juntos Pedro e o discípulo amado. Depois de Jesus anunciar que um dos discípulos o trairá (v. 21), instaura-se um mal-estar generalizado entre os comensais. É inegável que o discípulo que Jesus amava ocupa aqui um lugar de destaque, haja vista a sua localização na ceia: ele está ao lado de Jesus e pode reclinar sua cabeça sobre seu peito (vv. 23.25), evocando Jesus que está voltado para o seio do Pai $(1,18)$.

O texto não necessariamente apresenta uma relação hostil entre esses dois discípulos. Pedro pode não ter dirigido pessoalmente a pergunta a Jesus por uma questão logística: seu assento não era tão bom à mesa. Todavia, ele tira proveito da proximidade do discípulo amado e por meio dele tenta identificar o traidor. ${ }^{54}$ Ademais, nada no texto indica que o discípulo amado pretendesse

\footnotetext{
${ }^{51}$ BROWN, R., El Evangelio según Juan, p. 876, v.2. (tradução nossa). LÉON-DUFOUR, X., Lectura del Evangelio de Juan, p. 30, v.3.

${ }^{52}$ BROWN, R., El Evangelio según Juan, p. 874, v.2.

${ }^{53}$ BLAINE JR., B. B., Peter in the Gospel of John, p. 67.

54 “O gesto de Simão Pedro, levando esse discípulo a fazer a pergunta a Jesus, pode destacar a
} 
colocar a pergunta se não tivesse sido motivado por Pedro, ${ }^{55}$ razão pela qual os dois não podem ser vistos como adversários, mas colaboradores. ${ }^{56}$

Por fim, só depois que Judas sai da sala após receber o pão passado no molho (v. 30), é que Jesus entrega aos discípulos o mandamento do amor (v. 34) e anuncia a sua partida iminente (v. 33). Dirigindo-se a Pedro, diz Jesus: "Para onde eu vou, não podes agora seguir-me, mas depois me seguirás ("O $\pi$ ov

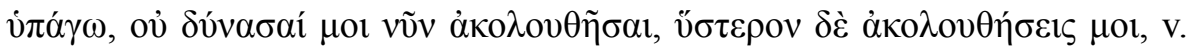
36). Pedro contesta: "Senhor, por que não posso te seguir imediatamente?"

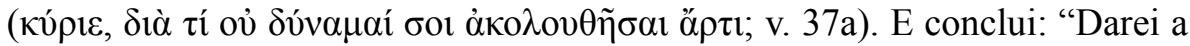
minha vida por ti” (

Nos sinóticos temos uma formulação ligeiramente diversa. Em Marcos se diz: "Ainda que me seja necessário morrer contigo, de modo

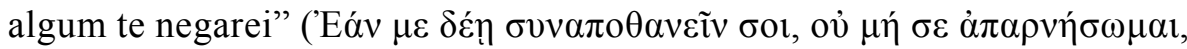
Mc 14,31). A formulação de Mateus, com pequenas mudanças, é a mesma (Mt 26,35). Já Lucas traz: "Senhor, eu estou pronto para ir contigo para a

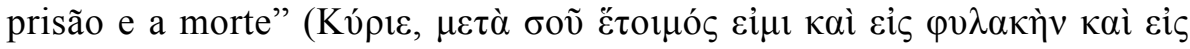

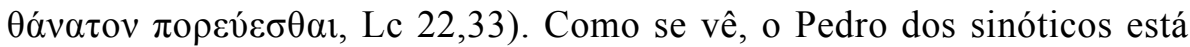
disposto a acompanhar Jesus até à morte, ao passo que o de João está disposto a entregar sua vida para salvar a de Jesus. ${ }^{57}$ "O desejo de Pedro dar sua vida por Jesus é sincero, mas a coragem necessária para realizar o ato ainda não estava madura". ${ }^{58}$

\subsection{Prisão e negações $(18,1-26)$}

Todos os evangelistas narram com bastante carga dramática o episódio da prisão de Jesus. João fala que no momento da prisão Judas Iscariotes estava acompanhado da coorte romana e da guarda do Templo $(18,3)$. A palavra $\sigma \pi \varepsilon i ̃ \rho \alpha$,

\footnotetext{
posição privilegiada desse discípulo. É possível distinguir uma certa competição entre os dois discípulos em 20:2-8; 21:7,20-22, mas não em detrimento de Pedro e de sua posição (6:68f; 21:15-17). A intenção, ao contrário, é a de colocar em evidência o outro discípulo reforçando o reconhecimento da autoridade de Pedro e de sua intimidade e proximidade com Jesus" (SCHNACKENBURG, R., The Gospel according to St. John, p. 30, v.3). Tradução nossa.

${ }^{55}$ BLAINE JR., B. B., Peter in the Gospel of John, p. 73. QUAST, K., Peter and the Beloved Disciple, p. 63.69.

${ }^{56}$ Não obstante isso, Cullmann afirma que existe uma clara rivalidade entre Pedro e o discípulo

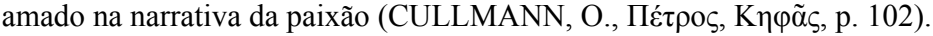

${ }^{57}$ BROWN, R., El Evangelio según Juan, p. 933-934, v.2.

${ }^{58}$ BLAINE JR., B. B., Peter in the Gospel of John, p. 77 (tradução nossa).
} 
aqui traduzida por coorte, era um termo militar que designava um décimo de uma legião, ou seja, cerca de 500 soldados. ${ }^{59}$ Ao ser identificado por Judas Iscariotes, os soldados prendem Jesus e tem início um certo tumulto que culmina num episódio de violência: um dos discípulos toma uma espada e fere a orelha de um dos servos do sumo sacerdote (Mc 14,47; Mt 26,51). Lucas informa que se tratava da orelha direita do servo $(22,50)$. Nos três casos, o discípulo permanece anônimo.

É apenas João quem identificará esse discípulo com Simão Pedro: "Simão Pedro, que tinha uma espada, desembainhou-a e feriu o servo do sumo

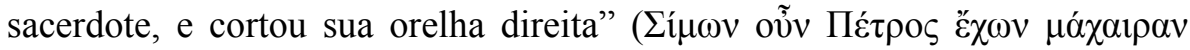

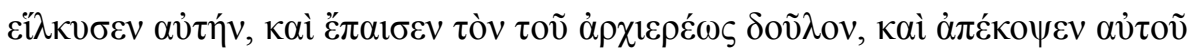

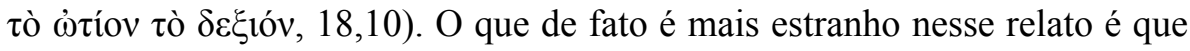
um discípulo de Jesus, depois de receber o mandamento do amor, ainda conservasse consigo uma espada ${ }^{60} \mathrm{~A}$ atitude de Simão Pedro é completamente desnecessária, pois Jesus está no controle da situação.

De qualquer forma, o gesto de Pedro, diante de um quadro tão adverso, não deixa de ter um quê de heroico. Ele pretendia proteger Jesus e foi essa intenção que o motivou a agir daquela forma. Jesus corrige a atitude de Pedro

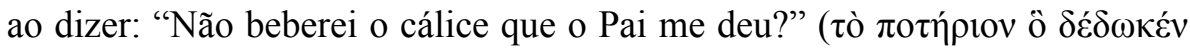

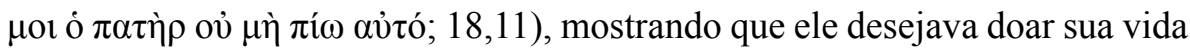
conforme o desígnio do Pai.

A seguir, o evangelista descreve o julgamento religioso de Jesus. Este é um dos momentos mais significativos da história de Simão Pedro. Apesar de ele ser um herói nos evangelhos sinóticos, todos eles narram as suas negações (Mc 14,66-72; Mt 26,69-75; Lc 22,55-62). No IV Evangelho, ainda que Pedro tenha fracassado de maneira clamorosa, o evangelista oferece algumas notas peculiares.

Primeiramente, em Jo 18,15, uma vez que Jesus fora conduzido ao palácio do sumo sacerdote, encontra-se o seguinte: "Porém, Simão Pedro, com o outro

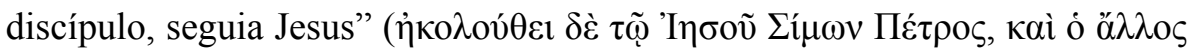
$\mu \alpha \theta \eta \tau \eta ́(\varsigma)$. Ainda que tal seguimento redunde em falência, percebe-se aqui um amor que o faz vencer o medo e acompanhar o Mestre.

Em Jo 18,16 informa que coube ao discípulo amado introduzir Simão Pedro no pátio do sumo sacerdote, por ser um conhecido dele. Aqui fica difícil

${ }^{59}$ SCHNEIDER, G., $\sigma \pi \varepsilon i ̃ \rho \alpha$, col. 1383.

${ }^{60} \mathrm{Em}$ seu discurso de despedida Jesus tinha advertido que os discípulos seriam expulsos das sinagogas $(16,2)$, dispersos $(16,32)$ e mortos $(16,2)$. Teria ele se precavido contra essas ameaças? Essa hipótese é ventilada por BLAINE JR., B. B., Peter in the Gospel of John, p. 88. 
aceitar a hipótese de que o discípulo amado fosse o galileu anônimo de 1,37. Nesse caso, seria pouco provável que ele mantivesse algum tipo de relação com o sumo sacerdote em Jerusalém. Segundo o texto, o discípulo amado se recusou a prosseguir sem Pedro. ${ }^{61}$

Diferentemente dos sinóticos que narram todas as negações ao mesmo tempo, João as intercala com o interrogatório de Jesus. Na visão do quarto evangelista, Mestre e discípulo são submetidos simultaneamente à prova, ambos devem dar testemunho da verdade, mas é aqui que Pedro falha. João não é tão duro quanto Marcos segundo o qual Pedro começou a "praguejar

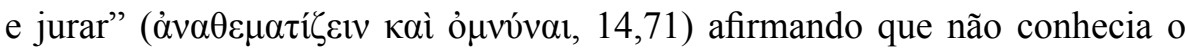
Senhor. Apesar disso, todos os sinóticos falam do choro de Pedro após as negações (Mc 14,72; Mt 26,75; Lc 22,62) e João nada diz a esse respeito.

Seja como for, um elemento das negações se une ao texto de 21,1-14. Em Jo 18,18 o evangelista afirma que Simão Pedro, ao entrar no pátio do sumo sacerdote, estava junto de uma fogueira se aquecendo. A outra única ocorrência

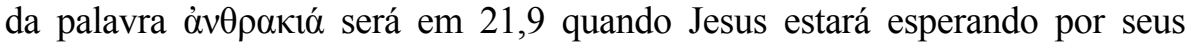
discípulos nas margens do mar de Tiberíades com uma fogueira e uma refeição preparada. Com acerto se pode afirmar que o cenário é semelhante a fim de que as três negações sejam "curadas" pela tríplice afirmação de amor (21,15-17).

\subsection{A manhã da ressurreição (20,1-10)}

A manhã da ressurreição começa com a descoberta, por parte de Maria Madalena, de que o sepulcro estava vazio e a pedra fora retirada $(20,1)$. Ela vai até Simão Pedro e ao outro discípulo para lhes dar a sua versão do fato: "Retiraram

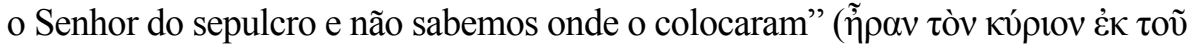

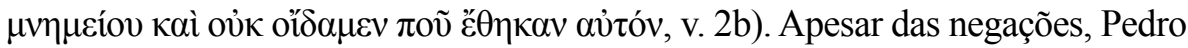
ainda é visto pelos discípulos como uma referência na comunidade. É a partir

\footnotetext{
${ }^{61}$ BLAINE JR., B. B., Peter in the Gospel of John, p. 93.97. Brodie vê aqui uma espécie de maquinação do discípulo anônimo contra Pedro. Para ele, esse discípulo seria Judas Iscariotes, que conhecia o sumo sacerdote, e teria delatado Pedro para a porteira. Conforme suas palavras: "Nesse ponto existem conotações da queda (Gn 3): a figura satânica (a serpente, Judas) com o conhecimento superior fala com a mulher, e quando a mulher fala com o (representante) homem ("Adão", Pedro), ele cede e segura o conforto da criatura (alimento, para Adão; calor, para Pedro). A essência de ambos os textos é a negação de uma verdadeira relação com Deus ("Eu não sou" de Pedro, ouk eimi, é uma contradição direta do divino "Eu sou" de Jesus, egō eimi, 18:5,8)": BRODIE, T. L., The Gospel according to John, p. 529 (tradução nossa). Como se depreende, tal relação é bastante imaginativa e carece de fundamentação textual.
} 
desse ponto que a interpretação dada pelos exegetas começa a ficar curiosa.

Quase que a modo de refrão, os estudiosos descrevem essa ida do discípulo amado e Pedro ao túmulo como se fosse uma competição na qual o primeiro saiu vitorioso. ${ }^{62}$ Para Brown, era uma questão de amor. O discípulo amado amava mais que Pedro, por isso chegou mais rápido. ${ }^{63} \mathrm{Na}$ Catena Áurea, Tomás de Aquino reporta um comentário atribuído a Gregório Magno segundo o qual Pedro representa os gentios que demoraram mais para chegar à fé em Jesus. ${ }^{64}$ Para Brodie, o discípulo amado chega mais rápido porque está em melhores condições físicas. ${ }^{65}$ Ao interpretarem a ida ao túmulo como uma disputa, os estudiosos devem retirar do texto interpretações polêmicas. ${ }^{66}$

O discípulo amado chega ao sepulcro primeiro, constata que as coisas estavam como Maria Madalena havia descrito, mas não entra (v. 4-5). Por fim chega Pedro, que entra no túmulo e observa os panos de linho e o sudário (vv. 6-7). Os verbos empregados para indicar a ação de "ver" são distintos. Tanto nos vv. 1 e 5, o "ver" de Maria Madalena e do discípulo amado é descrito pelo verbo $\beta \lambda \varepsilon ́ \pi \omega$, que na teologia joanina indica uma visão mais simples. Já para o "ver" de Pedro no sepulcro o evangelista emprega o verbo $\theta \varepsilon \omega \rho \varepsilon ́ \omega$, que indica um esforço de compreensão. Não fazia sentido que o corpo tenha sido roubado e os panos que o envolviam tivessem sido deixados.

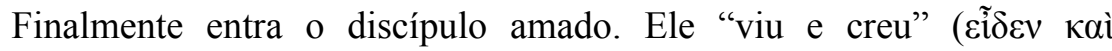

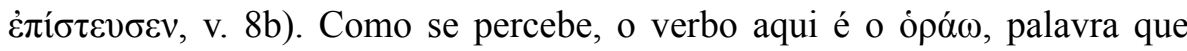
sempre será utilizada para descrever as visões do Ressuscitado $(20,20.25 .29)$. Ele descreve um ver mais profundo que culmina na fé. ${ }^{67} \mathrm{O}$ discípulo amado

\footnotetext{
${ }^{62}$ Assim Bultmann, que interpreta os discípulos como representantes do cristianismo judeu e gentílico (BULTMANN, R., The Gospel of John, p. 685). Para Maynard, "Diz-se que Pedro chegou depois - literalmente 'seguindo' - o Discípulo Amado. Uma vez que o termo 'seguir' é um termo técnico para se tornar um discípulo no Quarto Evangelho, é provável que aqui ele seja usado para subordinar Pedro ao Discípulo Amado. (...) Pedro não termina bem nessa história!" (MAYNARD, A. H., The role of Peter in the Fourth Gospel, p. 540, tradução nossa).

63 "Quanto ao episódio de 20,3-10, a pressa com que os dois discípulos acodem ao sepulcro expressa sua preocupação de escutar as notícias dadas por Madalena; essa preocupação brota do amor, razão pela qual não é de se estranhar que o discípulo amado se adiante a Pedro, pois ama mais a Jesus” (BROWN, R., El Evangelio según Juan, p. 1438, v.2, tradução nossa).

${ }^{64}$ TOMÁS DE AQUINO, Catena Aurea.

65 "O fato de o discípulo amado correr mais rápido não indica que ele fosse mais jovem, mas simplesmente significa que ele, literalmente, estava em melhores condições de corrida": BRODIE, T. L., The Gospel according to John, p. 561, tradução nossa.

${ }^{66}$ BLAINE JR., B. B., Peter in the Gospel of John, p. 113.

${ }^{67}$ Para maior aprofundamento, vide MANNS, F., En marge des récits de la résurrection: le
} 
é essa testemunha que sabe interpretar os sinais e reconhecer a verdade neles contida, é ele quem tem a inteligência da fé. No entanto, é ainda uma fé incipiente, pois dos dois discípulos se diz: "Com efeito, ainda não sabiam

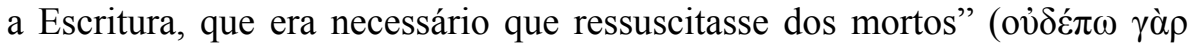

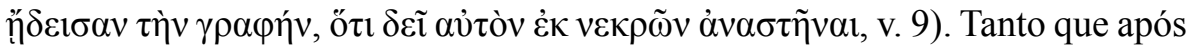
entrar no sepulcro, eles voltaram para casa (v. 10) e o evangelista nada diz acerca de um eventual testemunho do discípulo amado. ${ }^{68}$

\section{Conclusão}

Tendo feito esse percurso crítico, é oportuno retornar à pergunta inicial do artigo: o cap. 21 do evangelho de João teria a pretensão de reabilitar uma pretensa imagem fraturada de Simão Pedro? Quereria o redator subordinar Pedro ao discípulo amado, estando subjacente uma disputa entre duas correntes do cristianismo primitivo? Ora, como se viu, aquilo que se afirma sobre um possível conflito entre correntes de cristianismo existe mais nas teorias dos exegetas do que no texto em si.

É inegável que o discípulo amado é o herói por excelência do IV Evangelho. É ele quem encarna o modelo ideal de discípulo a ser buscado pela comunidade. Como responsável e catequista da comunidade, é natural que seja visto como alguém de destaque. Contudo, afirmar isso não implica no rebaixamento de Pedro ou que necessariamente houvesse uma contenda entre eles. A figura de Simão Pedro, com todas as suas luzes e sombras, não precisa ser reabilitada porque, como se vê, ao longo do evangelho, não foi pintada de maneira hostil.

Simão Pedro e o discípulo amado são modelos de discipulado e os dois se completam. No discípulo amado temos o amor pelo Mestre, a intimidade com o Senhor, o olhar profundo que lhe permite perceber as circunstâncias à luz da fé. Mas só isso não basta para fazer um discípulo segundo a concepção joanina. Em Pedro temos o desejo de seguir, o ímpeto da ação e, sobretudo, a força do testemunho. Em nome dos discípulos ele professa a sua fé e coube a ele trazer, no final do evangelho, a "multidão de peixes" para junto de Jesus, e a rede não se rompeu. Aquilo que se via ao longo do evangelho, no cap. 21 é ainda mais evidente, a saber, que os dois discípulos se completam e encarnam o ideal do discipulado em Jo.

Gnilka, ao comentar a imagem de Pedro no IV Evangelho, também

verbe "voir", p. 431-448.

${ }^{68}$ BLAINE JR., B. B., Peter in the Gospel of John, p. 106. 
percebe essa dimensão de complementariedade entre ele e o discípulo amado. Ele afirma que:

Deparamo-nos, mais uma vez, com a confrontação entre Simão Pedro e o discípulo amado no quarto evangelho. A cada um, respectivamente, foi destinado um caminho próprio no discipulado. A um foi assinalado o caminho da disponibilidade para o sofrimento e para o martírio, enquanto ao outro, a proximidade especial a Cristo. Isso não significa que o segundo seja poupado da cruz. Precisamente o discípulo amado permanece junto à cruz de Cristo. Simão Pedro experimenta a cruz fisicamente, em sua própria carne e, assim, completa seu discipulado. O discípulo amado torna-se testemunha do amor de Deus, que se revela na cruz de Cristo. Ambas as vias são válidas e paradigmáticas. Existe o caminho do martírio e o caminho da imediatidade de Cristo ou - se essa palavra pode ser aplicada - da mística. ${ }^{69}$

\section{Referências bibliográficas}

AGOURIDES, S. The purpose of John 21. In: DANIELS, B. L.; SUGGS, M. J. (Eds.). Studies in the History and Text of the New Testament in honor of Kenneth Willis Clark. Salt Lake City: University of Utah Press, 1967. p. 127-132.

BLAINE JR., B. B. Peter in the Gospel of John: The making of an authentic disciple. Atlanta: SBL, 2007.

BLASS, F.; DEBRUNNER, A. Grammatica del Greco del Nuovo Testamento. 2.ed. Brescia: Paideia, 1997.

BRODIE, T. L. The Gospel according to John: A literary and theological commentary. New York / Oxford: Oxford University Press, 1997.

BROWN, R. A Comunidade do Discípulo Amado. São Paulo: Paulus, 1999. BROWN, R. El Evangelio según Juan. Madrid: Ediciones Cristiandad, 1999. v.1.

BROWN, R. El Evangelio según Juan. Madrid: Ediciones Cristiandad, 1999. v.2.

BUlTMAnN, R. The Gospel of John: A commentary. Philadelphia: The Westminster Press, 1971.

${ }^{69}$ GNILKA, J., Pedro e Roma, p. 194. 
CABA, J. Cristo, pan de vida: Teología eucarística del IV Evangelio. Estudo exegético de Jn 6. Madrid: BAC, 1993.

CHARlesworth, J. J. (Ed.) The Old Testament Pseudepifrapha. New York: Doubleday \& Company, 1985. v.2.

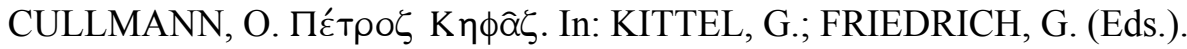
Theological Dictionary of the New Testament. Grand Rapids: Eerdmans Publishing Co., 2006. p. 100-112. v.6.

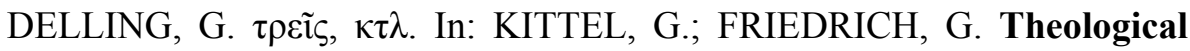
Dictionary of the New Testament. Grand Rapids: Eerdmans Publishing Company, 2006. p. 216-225. v.8.

DROGE, A. J. The status of Peter in the Fourth Gospel: A note on John 18:1011. Journal of Biblical Literature, v.109, n.2, p. 307-311, 1990.

ERBETTA, M. Gli Apocrifi del Nuovo Testamento. Casale: Marietti, 1975. V.I/1 (Vangeli).

EUSÉBIO DE CESAREIA. Historia Eclesiastica: Texto, versión española, introducción y notas por Argimiro Velasco-Delgado, OP. Madrid: BAC, 2001.

FITZMYER, J. A. Essays on the Semitic Background of the New Testament. Missoula: SBL / Scholars' Press, 1974.

GEE, D. H. Why did Peter spring into the sea? (John 21:7). Journal of Theological Studies, v.40, n.2, p. 841-849, 1989.

GNILKA, J. Pedro e Roma: A figura de Pedro nos dois primeiros séculos. São Paulo: Paulinas, 2006.

KEENER, K. S. The Gospel of John: A commentary. Grand Rapids: Baker Academic, 2012. v.2.

LAKE, K. Simon, Cephas, Peter. The Harvard Theological Review, v.14, n.1, p. 95-97, jan. 1921.

LÉON-DUFOUR, X. Lectura del Evangelio de Juan. Salamanca: Sigueme, 1995. v.3.

LÉON-DUFOUR, X. Lectura del Evangelio de Juan. Salamanca: Sigueme, 1998. v.4.

LIDDELL, H. G.; SCOTT, R. Greek-English Lexicon. With a revised supplement. Oxford: Clarendon Press, 1996. 
MAGGI, A. A Loucura de Deus: O Cristo de João. São Paulo: Paulus, 2013. MANNS, F. En marge des récits de la résurrection: le verbe "voir". In: MANNS, F. L'Evangile de Jean à la Lumière du Judaïsme. Jerusalem: Franciscan Printing Press, 1991. p. 431-448.

MANNS, F. Exégèse rabbinique et exégèse johannique. Le lavement des pieds. Essai sur la structure et la signification de Jean 13. In: MANNS, F. L'Evangile de Jean à la Lumière du Judaïsme. Jerusalem: Franciscan Printing Press, 1991. p. 321-337.

MATEOS, J.; BARRETO, J. El Evangelio de Juan: Analisis linguístico y comentario exegetico. Madrid: Cristiandad, 1982.

MAYNARD, A. H. The role of Peter in the Fourth Gospel. New Testament Studies, v.30, n.4, p. 531-548, out. 1984.

MINEAR, P. S. The original functions of John 21. Journal of Biblical Literature, v.102, n.1, p. 85-98, mar. 1983.

MOLONEY, F. J. EI Evangelio de Juan. Estella: Verbo Divino, 2005.

MOUlTON, J. H.; TURNER, N. A Grammar of New Testament Greek. Edinburgh: T \& T Clark, 1976. v.4.

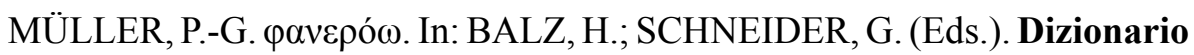
Esegetico del Nuovo Testamento. Brescia: Paideia, 2004. col. 1977-1769.

NESTLE-ALAND. Novum Testamentum Graece. 28.ed. Stuttgart: Deutsche Bibelgesellschaft, 2012.

OAKMAN, D. The political meaning of a cipher - John 21:11. Biblical Theology Bulletin, v.47, n.2, p. 87-94, mai. 2017.

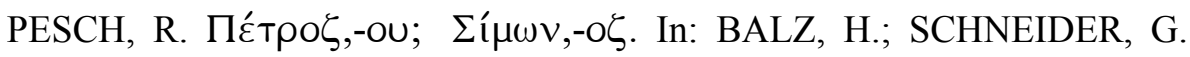
(Eds.). Dizionario Esegetico del Nuovo Testamento. Brescia: Paideia, 2004. col. 916-926.

QUAST, K. Peter and the Beloved Disciple: Figures for a community in crisis. Sheffield: JSOT Press, 1989.

SCHNACKENBURG, R. The Gospel according to St. John. Turnbridge Wells: Burns \& Oates, 1984. v.3.

SCHNEIDER, G. $\sigma \pi \varepsilon i ̃ \rho \alpha$. In: BALZ, H.; SCHNEIDER, G. (Eds.). Dizionario Esegetico del Nuovo Testamento. Brescia: Paideia, 2004. col. 1383. 
SCHNEIDERS, S. M. John 21:1-14. Interpretation, v.43, v.1, p. 70-75, jan. 1989.

SCOTT, J. M. A question of identity: Is Cephas the same person as Peter? Journal of Biblical Studies, v.3, n.3, p. 1-20, out. 2003.

SNYDER, G. F. John 13:16 and the Anti-Petrinism of the Johannine Tradition. Biblical Research, v.16, n.1, p. 5-15, jan. 1971.

TALBERT, C. Reading John: A literary and theological commentary on the Fourth Gospel and the Johannine Epistles. Macon: Smyth \& Hewys Publishing, 2005.

TOMÁS DE AQUINO. Catena Aurea. Disponível em: <https://www. ecatholic2000.com/catena/untitled-108.shtml\#_Toc384507008>. Acesso em: 17 nov. 2019.

VAN CANGH, J.-M. Le rôle de Pierre dans le Nouveau Testament. Revue Théologique du Louvain, v.11, n.3, p.41-62, 1980.

ZMIJEWSKI, J. $\pi \lambda \tilde{\eta} \theta$ oc. In: BALZ, H.; SCHNEIDER, G. (Eds.). Dizionario Esegetico del Nuovo Testamento. Brescia: Paideia, 2004.

ZORELL, F. Lexicon Graecum Novi Testamenti. Roma: Editrice Pontificio Istituto Biblico, 1999.

ZUMSTEIN, J. EI Evangelio según Juan (Jn 13-21). Salamanca: Sígueme, 2016. v.2.

Heitor Carlos Santos Utrini Doutor em Teologia Bíblica pela Pontificia Università San Tommaso D'Aquino Docente do Departamento de Teologia da Pontifícia Universidade Católica do Rio de Janeiro Rio de Janeiro / RJ - Brasil E-mail: hcsutrini@puc-rio.br

Recebido em: 30/09/19

Aprovado em: 07/10/19 